\title{
Evaluation of Coronally Advanced Flap In "L" Associated with Subepithelial Connective Tissue Graft In the Treatments of Miller's Class I and II Gingival Recessions
}

\author{
Evaluación de Colgajo Coronalmente Avanzado en "L" Asociado con Injerto Subepitelial de \\ Tejido Conectivo en el Tratamiento de Recesiones Gingivales de Clases I y II de Miller
}

Guilherme da Rocha Scalzer Lopes'; Jefferson David Melo de Matos; Leonardo Jiro Nomura Nakano'; Emanuelle Ambrosio Merlo; Juliana Candotti²; Marco Antonio Bottino'; Valdir Cabral Andrade ${ }^{3}$ \& Cristiano Hooper Pascoal $^{4}$

LOPES, G. R. S.; MATOS, J. D. M. ; NAKANO, L. J. N.; MERLO, E. A.; CANDOTTI, J.; BOTTINO, M. A.; ANDRADE, V. C. \& PASCOAL, C. H. Evaluation of coronally advanced flap in " L " associated with subepithelial connective tissue graft in the treatments of miller's class i and ii gingival recessions. Int. J. Odontostomat., 13(3):457-463, 2020.

ABSTRACT: To evaluate clinically the results of two surgical techniques used for root coverage, the coronally advanced flap in " L " isolated (CAF) or associated with subepithelial connective tissue graft (SCTG). The surgical procedures were performed in seventeen individuals, ten individuals in the control group (coronally advanced flap in "L") and seven individuals in the test group (coronally advanced flap in "L" associated with SCTG), who presented Miller class I and II gingival recession. The depth gingival recession (GR) index was evaluated in the following periods: immediate preoperative and 180 postoperative days. The control group had a success rate of $85+/-18 \%$ and the test group had a success rate of $95+/-4 \%$. The variable success rates $(p=0.36)$ did not present a statistically significant difference. The isolated CAF or its association with SCTG showed favorable outcomes in the treatments of Miller's class I and II gingival recessions.

KEY WORDS: periodontics, dental research, dentistry.

\section{INTRODUCTION}

Gingival recessions consist of the apical migration of its margin relative to the cementoenamel junction (CEJ), with root exposures that can cause smile disharmony (Baldi et al., 1999) and in some patients may also cause cervical hypersensitivity by exposing the region to the oral cavity. This problem affects both the population with low or high oral hygiene practice (Castellanos et al., 2006).

The primary etiological factors related to gingival recessions are inflammation due to biofilm accumulation and / or mechanical trauma during teeth brushing (Chambrone et al., 2010). In both cases the inflammatory process of the periodontal tissues will lead to the apical migration of the gingival margin, being able to be influenced by the gingival biotype (Cortellini et al., 2009). These primary factors may be aggravated by secondary factors such as dental positioning, the presence of muscle insertions near the gingival margins, restorative treatments with cervical margin misfit, traumatic periodontal procedures, among others (Hwang \& Wang, 2006).

According to Miller's classification, gingival retractions can be divided into 4 distinct classes according to the prognosis of root coverage. In Class $\mathrm{I}$, the recession of the marginal tissue does not reach the mucogingival line; therefore, no loss of bone and

\footnotetext{
${ }^{1}$ Program in Restorative Dentistry, Department of Dental Materials and Prosthodontics, São Paulo State University (Unesp), Institute of Science and Technology, São José dos Campos - SP, Brazil.

2 Faculdades Integradas Espírito-Santenses FAESA, Vitória - ES, Brazil.

${ }^{3}$ Oral and Maxillofacial Surgery, Department of Dentistry, Universidade Federal de Juiz de Fora UFJF, Governador Valadares - MG, Brazil.

${ }^{4}$ Oral Implantology, Department of Dentistry, Faculdades Integradas Espírito-Santenses FAESA, Vitória - ES, Brazil.
} 
LOPES, G. R. S.; MATOS, J. D. M. ; NAKANO, L. J. N.; MERLO, E. A.; CANDOTTI, J.; BOTTINO, M. A.; ANDRADE, V. C. \& PASCOAL, C. H. Evaluation of coronally advanced flap in " L " associated with subepithelial connective tissue graft in the treatments of miller's class i and ii gingival recessions. Int. J. Odontostomat., 13(3):457-463, 2020.

interproximal soft tissue (Zucchelli \& De Sanctis, 2005). In Class II, the recession reaches or exceeds the mucogingival line, but there is no loss of bone or soft tissue interproximal (Sculean et al., 2017). In Class III, the recession reaches or exceeds the mucogingival line. However, bone or interproximal soft tissue loss is coronary to the apical limit of the recession (Ucak et al., 2017). Class IV is a more aggressive form and is characterized by a marginal recession that reaches or exceeds the mucogingival line, in addition, interproximal bone loss is apical to the limit of the recession (Sculean et al., 2016). to the predictability of root coverage, Class I and II have a $100 \%$ chance of being reached. Class III is only possible to cover the root of 25 to $50 \%$ of the cases, in this way the coating may present in a partial way. Finally, in cases that present Class IV, it is eliminated any possibility of predicting root coverage (Chaparro et al., 2015).

Periodontal plastic surgery is considered any surgical procedure performed to prevent, correct or eliminate anatomical defects, inflammatory or traumatic development of the periodontal soft tissues (Nart \& Valles, 2016). It consists of a huge variety of mucogingival procedures, including root coverage (Pini Prato et al., 2000).

Therefore, the objective of the study is to evaluate clinically the results of two surgical techniques used for root coverage, the coronally advanced flap in " $L$ " isolated (CAF) or associated with the subepithelial connective tissue graft (SCTG).

\section{MATERIAL AND METHOD}

Seventeen patients with recessions class I and II of Miller were selected and at the beginning of the clinical and radiographic examination, the patients were informed about the proposal of the study, its risks and benefits and asked to sign the Informed Consent Term.

Inclusion criteria were: good systemic health, absence of pathologies or use of medications that have known periodontal health interferences, non-smokers, patients who presented at least one isolated site of gingival recession classes I and II, with probing pocket depths between 3 and $4 \mathrm{~mm}$, involving incisors, canines or pre-molar teeth, and the teeth involved should present a good positioning in relation to the alveolar bone.
Before the surgical procedures, the patients underwent an initial periodontal therapy with the purpose of controlling the biofilm. The bleeding on probing index was kept below $20 \%$. This same value was used as reference for biofilm control. Clinical photographs of the sites were made in the immediate preoperative period, in the immediate postoperative period and at 180 postoperative days.

To perform the intra-examiner calibration, before the beginning of the research, the selected professional was submitted to the Kappa test. The extension of the gingival recession was evaluated in the immediate preoperative period and at 180 postoperative days. All measurements were performed for each tooth using a periodontal probe (PCPNU $15 \mathrm{Hu}$-Friedy Inc., Chicago, IL, USA).

Surgical technique of the control group. An intraoral antisepsis with $0.1 \%$ chlorhexidine digluconate for 1 minute followed by an extra-oral antisepsis with 2 $\%$ chlorhexidine digluconate were performed. The surgical technique was coronally advanced flap in "L". After recording the clinical parameters evaluated in the study, a specific anesthesia was performed for each region, with $2 \%$ lidocaine hydrochloride solution, with adrenaline in the concentration of 1:100.000.

Previously the incisions were measured the extension of the gingival recession. Then, this measurement was increased by $1 \mathrm{~mm}$ and transposed, parallel to the tooth, to the distal papilla from the edge of the papilla. The projection of this point toward the tooth marks the vertex between the incisions, which should mimic the papilla without recession.

The first incision began intra-sulcular at the dihedral angle of the mesial papilla extending to the dihedral angle of the distal papilla of the tooth affected by the gingival recession. A second incision was made following the first, in the distal papilla, forming a sketch to copy the contour of this papilla, following the limit determined by the preoperative probe mentioned above. The third incision, relaxing vertical, is extended from the incision of the papilla, until it exceeds the mucogingival line. This incision was made in a beveled and semicircular manner to favor the adaptation of repositioned edges of the flap, improving the esthetics while reducing the risk of fibrous scars (Fig. 1).

A mixed flap was realized, initially of total thickness, until it exceeds the mucogingival line (Fig. 2), followed by a divided flap, thus eliminating the 
strains of this flap in a coronally repositioning, favoring its better final adaptation (Fig. 3). The papilla and the margins of the relaxing incision were de-epithelialized where the flap was stabilized in its new position. This de-epithelialization was done through a $15 \mathrm{C}$ scalpel blade or micro scissors for papilla.

The flap was stabilized and coronally sutured, covering the exposed root surface. Abundant irrigation was performed throughout the procedure, with precooled saline solution. All incisions were made with a $15 \mathrm{C}$ blade.

The specific suture for the flap was initiated on the vestibular of the flap $6 \mathrm{~mm}$ from the vertex of the papilla formed in the flap. It then penetrated the base of the anatomical papilla through the vestibular, exiting the epithelium of the palatine papilla. Through the palatal the needle passes through the interproximal space of the mesial papilla, leaving the gingival sulcus of the tooth with recession. Subsequently the needle was introduced in the connective tissue direction for epithelial tissue $6 \mathrm{~mm}$ from the dihedral angle of the mesial of the tooth, internally dividing the gingival margin. The coronal $2 \mathrm{~mm}$ at this point the needle was again introduced by the epithelial tissue, returning through the gingival sulcus, leaving the palatal epithelial tissue of the mesial papilla. The needle was then introduced again on the palatine side of the distal papilla exiting the vestibular. Repeating these distances of $2 \mathrm{~mm}$ coronal, the needle is running through by the connective tissue of the flap exposing itself in the vestibular, finalizing the node at that moment.

Without cutting the thread, the needle was again inserted into the flap $2 \mathrm{~mm}$ from the apex of the created papilla, crossing the papilla from the vestibular to the palatine in the distal papilla. Passing through the mesial interproximal space without penetrating the distal papilla this time around the palatine and exiting the mesial vestibular sulcus of the tooth. The needle was crossed from the epithelial tissue to the connective tissue $2 \mathrm{~mm}$ from the dihedral angle, returning through the distal point of contact, passing through the vertex of the anatomical papilla and ending in a simple node. Subsequently single isolated sutures were made in the relaxing incision, always starting towards the nondisplaced tissue, avoiding trapping of this flap and compromising the other sutures (Fig. 4).

Surgical technique of the test group. The technique used was coronally advanced flap in "L" but associated with subepithelial connective tissue graft.

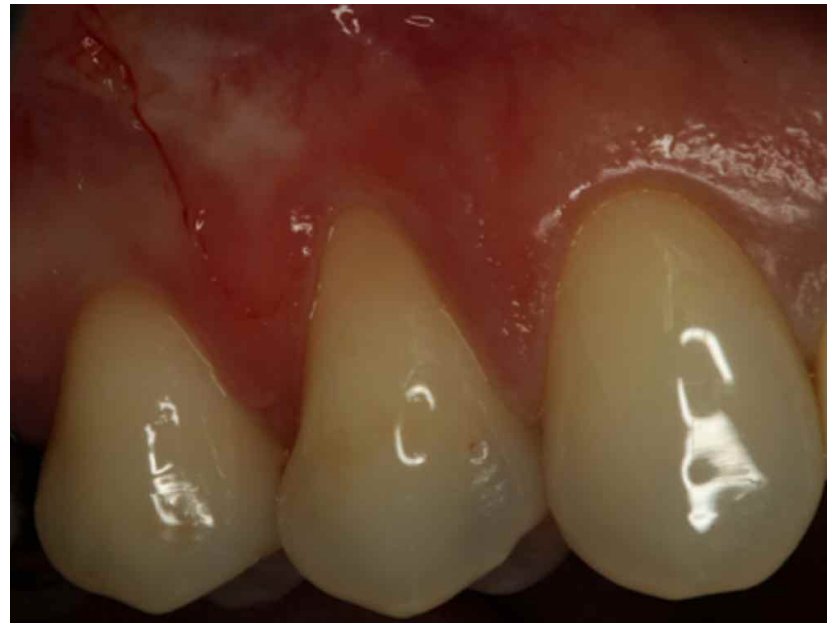

Fig. 1. The three incisions forming a sketch to copy the distal papilla.

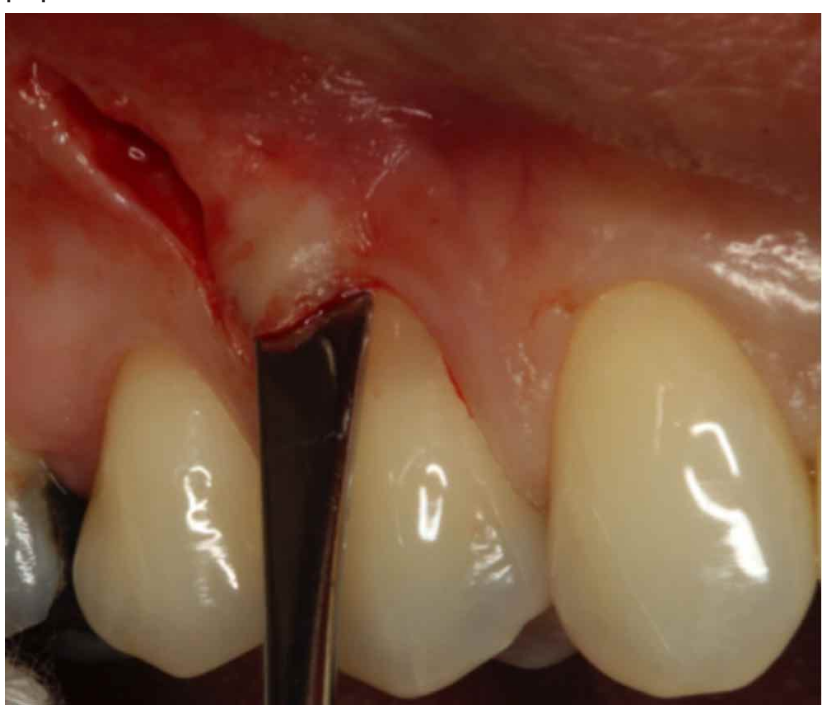

Fig. 2. Initial detachment of the flap of total thickness until it exceeds the mucogingival line.

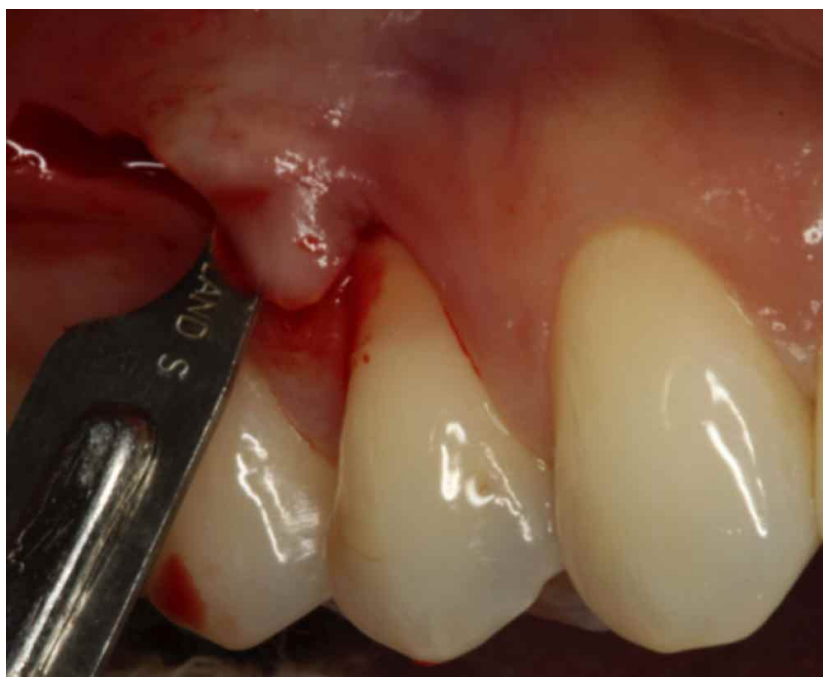

Fig. 3. Division of the flap from the mucogingival line. 


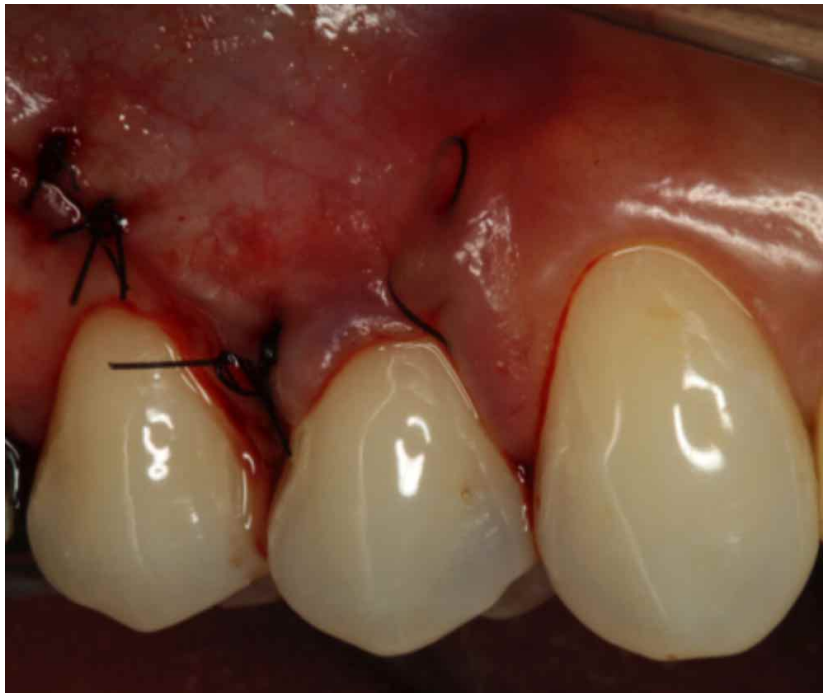

Fig. 4. immediate post-operative.

In the postoperative care was prescribed Paracetamol $750 \mathrm{mg}(1 \mathrm{comp}$ of 6 / 6 h only on the first day) and Meloxicam $7.5 \mathrm{mg}$ (single daily dose for three days). Patients were instructed to refrain from brushing and flossing the area involved in the surgery until the removal of the suture (14 days). They were also instructed to consume soft foods in the first week and avoid mechanical trauma on the area.

During the first 4 weeks, mouthwash was used with $0.12 \%$ chlorhexidine digluconate for 1 minute, 3 times daily. All patients underwent biofilm control by the clinician, weekly in the first month and monthly until the end of the study (6 months).
Statistical analysis. In the present study, the individual was a sample unit. The variables were analyzed statistically and, according to the type of variable to be tested (categorical or numerical), the most indicated statistical test was applied.

In this context, the surgical procedures variable presents two distinct levels (control and test group). When tested with numerical (quantitative) variables, a normality analysis was applied (assumption of several parametric tests) and, according to the result, the Kruskal-Wallis test was adopted.

Statistical tests were performed in R-project 3.2.0 statistical software. The level of significance established for the tests was $5 \%$, which established a $95 \%$ confidence interval for the presented results.

\section{RESULTS}

Control group. The control group presented a total of ten individuals. In the initial evaluation, an average value of $3.4+/-0.48 \mathrm{~mm}$ of gingival recession (GR) was observed. In the final evaluation, the mean values found were $0.6+/-0.72$ of GR. Comparing the values obtained in these evaluations it can be observed that there was an average gain of $2.8+/-0.72 \mathrm{~mm}$ of root coverage, that showed a success rate of $85+/-18 \%$, as shown in Table I.

Test group. The test group consisted of seven individuals. In the initial evaluation, the mean value of

Table I. Control group.

\begin{tabular}{lccrrr}
\hline Individuals & $\begin{array}{c}\text { GR Pre- } \\
\text { Operative }\end{array}$ & $\begin{array}{c}\text { GR 180 Days Post- } \\
\text { Operative }\end{array}$ & GR & Relative Value & Root Coverage \\
\hline P1 & 3 & 0 & 0 & $0.0 \%$ & $100.0 \%$ \\
P2 & 4 & 1 & 1 & $25.0 \%$ & $75.0 \%$ \\
P3 & 3 & 0 & 0 & $0.0 \%$ & $100.0 \%$ \\
P4 & 4 & 1 & 1 & $25.0 \%$ & $75.0 \%$ \\
P5 & 3 & 0 & 2 & $50.0 \%$ & $100.0 \%$ \\
P6 & 4 & 2 & 2 & $50.0 \%$ & $50.0 \%$ \\
P7 & 4 & 2 & 0 & $0.0 \%$ & $100.0 \%$ \\
P8 & 3 & 0 & 0 & $0.0 \%$ & $100.0 \%$ \\
P9 & 3 & 0 & 0 & $0.0 \%$ & $100.0 \%$ \\
P10 & 3 & Residual Average 0.6 & 0.6 & & \\
Initial Average & 3.4 & Standard Deviation 0.72 & 0.72 & & \\
Standard Deviation & 0.48 & & & \\
Success of the Treatment & $85.0 \%$ & & & \\
Standard Deviation & $18.0 \%$ & & & & \\
\hline
\end{tabular}


LOPES, G. R. S.; MATOS, J. D. M. ; NAKANO, L. J. N.; MERLO, E. A.; CANDOTTI, J.; BOTTINO, M. A.; ANDRADE, V. C. \& PASCOAL, C. H. Evaluation of coronally advanced flap in " L " associated with subepithelial connective tissue graft in the treatments of miller's class i and ii gingival recessions. Int. J. Odontostomat., 13(3):457-463, 2020.

Table II. Test group.

\begin{tabular}{lccrc}
\hline Individuals & $\begin{array}{c}\text { GR Pre- } \\
\text { Operative }\end{array}$ & $\begin{array}{c}\text { GR 180 Days Post- } \\
\text { Operative }\end{array}$ & $\begin{array}{c}\text { Relative } \\
\text { Value }\end{array}$ & Root Coverage \\
\hline PT 1 & 4 & 0 & $0.0 \%$ & $100.0 \%$ \\
PT 2 & 2 & 0 & $0.0 \%$ & $100.0 \%$ \\
PT 3 & 4 & 0 & $0.0 \%$ & $100.0 \%$ \\
PT 4 & 2 & 0 & $0.0 \%$ & $100.0 \%$ \\
PT 5 & 4 & 0.5 & $12.50 \%$ & $87.50 \%$ \\
PT 6 & 2 & 0.5 & $0.0 \%$ & $100.0 \%$ \\
PT 7 & 3 & Residual Average & 0.14 & \\
Initial Average & 3 & Standard Deviation 0.66 & & \\
Standard Deviation & 0.96 & & & \\
& & & & \\
Success of the Treatment & $95.83 \%$ & & & \\
Standard Deviation & $4.00 \%$ & &
\end{tabular}

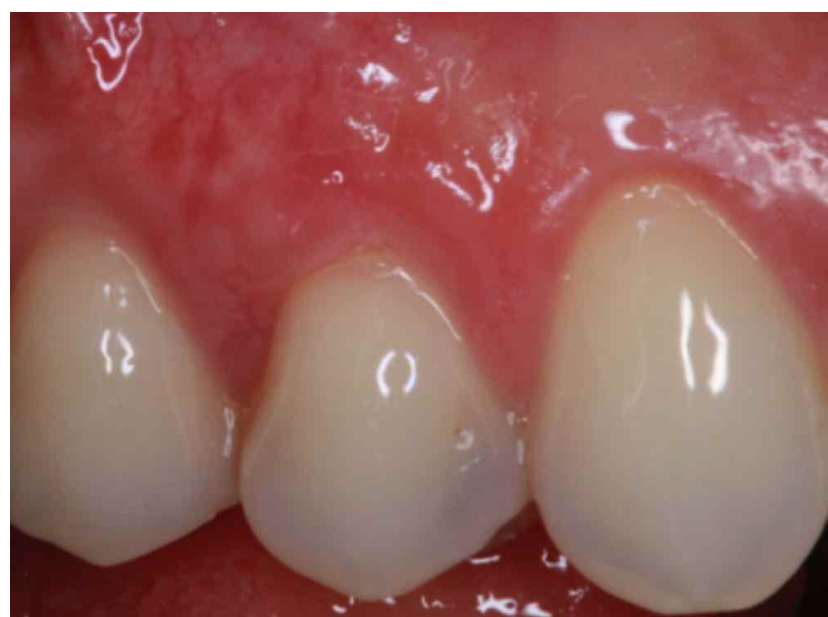

Fig. 5. Post-operative with 180 days.

$3.0+/-0.96 \mathrm{~mm}$ of $\mathrm{GR}$ was observed. In the final evaluation, the mean values found were $0.14+/-$ $0.66 \mathrm{~mm}$ of GR, showed a success rate of $95+/-4 \%$, as shown in Table II.

Regarding the surgery technics (control and test group), the variable success rate $(p=0.36)$ did not present a statistically significant difference.

\section{DISCUSSION}

The prognosis of root coverage of Miller's class I and II gingival recession is very favorable, reaching an average of $85 \%$ of success rates when using the coronally advancement flap technique (CAF) (Pini Prato et al., 2005). In addition, this surgical procedure is shown with low morbidity level. This morbidity is greater when associated with the connective tissue graft. On the other hand, the prognosis of root coverage seems to be more favorable when there is an association of techniques (Berlucchi et al., 2005).

Some studies assume that the thickness of the flap could influence the clinical results in the coverage of gingival recessions using the CAF. Their results indicate that there is a direct relationship between the thickness and the prognosis of the treatment, CAF is a useful and predictable surgical technique for the treatment of minor gingival recessions and the greater the tension in the flap, the worse the outcome in the treatment of recession (Saletta et al., 2001; Pini Prato et al., 2018). Therefore, thick gingival tissue is a prerequisite for surgical success, as it facilitates manipulation, maintains vascularization and facilitates surgical wound healing (Straub et al., 2006). Another factor that can influence the complete coverage of the root with CAF is the height of the adjacent papillae. However, the papilla area does not appear to interfere with the prognosis of treatment (Zucchelli \& De Sanctis, 2013).

Regarding the stability of the long-term root coverage, it can be observed that the results can be maintained than 5 years, provided that the patient is aware of the necessary care and is preferably inserted in a periodontal support therapy program, to prevent recessions. However individual susceptibility to recession and genetically determined mucogingival position are directly related to maintaining the positioning of the gingival margin (Guttiganur et al., 2018). 
Several studies propose to approach alternative techniques that aim to improve the results and predictability of gingival recession treatments. In the study comparing CAF with or without the addition of enamel matrix derivative (EMD), a greater root coverage was observed in the places where EMD was used than the isolated CAF, regardless of arc or Miller's classification (Zucchelli \& De Sanctis, 2000). Other authors corroborate these results, considering that the addition of EMD may improve the clinical outcomes. However, they make it clear that both procedures (CAF + EMD e CAF) allow a root coverage and gain of periodontal clinical attachment with acceptable esthetic results (Sculean et al., 2014).

In studies comparing CAF alone or associated with subepithelial connective tissue graft (SCTG), it is observed that both surgical approaches are effective for root coverage. However, when it is desired to increase the gingival dimensions, to increase the keratinized tissue range or the thickness of the gingiva and / or mucosa, the combined technique (CAF + ETCSE) is shown to be more effective (Van Zyl \& Botha, 2001). Other authors, using a randomized controlled multicenter study, compared the root coverage with isolated CAF and with the SCTGE in the treatment of Miller's class I and II recessions. The reduction of the recession was not statistically different between the two groups, although one model showed a tendency for better results in SCTG treated sites. The dentin hypersensitivity significantly improved in the individuals of both groups. Both treatments were effective in significantly reducing gingival recession and dentin hypersensitivity (Minsk et al., 2002; Kang \& Fien, 2008). Similarly, in the present study, in the comparative evaluation between the control group and the test group, a more favorable prognosis was observed when the association of the techniques. However, it was observed that the two therapies were effective for the treatment of Miller's class I and II recessions of isolated teeth, without a statistically significant difference between the two surgical techniques.

The CAF isolated or associated with SCTG can be used as safe and predictable treatments in the root coverage of recessions class I and II of Miller. In cases where, in addition to the root coverage, an increase in the amount of keratinized tissue is expected, the use of SCTG seems to be more adequate (Nart et al., 2012). The use of the SCTG modifies the biotype of the gingival tissue making it more resistant to traumas, thus reducing the risk of new recessions. Therefore, the long-term outcome should be more stable when there is the association of surgical techniques (Roman et al., 2013; Rubins et al., 2013).

\section{CONCLUSION}

It can be concluded from this study that the isolated CAF or its association with SCTG showed favorable outcomes in the treatment of Miller's class I and II gingival recessions.

LOPES, G. R. S.; MATOS, J. D. M. ; NAKANO, L. J. N.; MERLO, E. A.; CANDOTTI, J.; BOTTINO, M. A.; ANDRADE, V. C. \& PASCOAL, C. H. Evaluación de colgajo coronalmente avanzado en "L" asociado con injerto subepitelial de tejido conectivo en el tratamiento de recesiones gingivales de clases I y II de Miller. Int. J. Odontostomat., 13(3):457-463, 2020.

RESUMEN: El objetivo fue evaluar clínicamente los resultados de dos técnicas quirúrgicas utilizadas para la cobertura radicular, el colgajo coronalmente avanzado en "L" aislado (CAF) o asociado con injerto de tejido conectivo subepitelial (SCTG). Los procedimientos quirúrgicos se realizaron en diecisiete individuos, diez individuos en el grupo de control (colgajo coronario avanzado en "L") y siete individuos en el grupo de prueba (colgajo coronalmente avanzado en "L" asociado con SCTG), que presentaron la clase I de Miller y II recesión gingival. El índice de recesión gingival profunda (RG) se evaluó en los siguientes períodos: preoperatorio inmediato y 180 días postoperatorios. El grupo de control tuvo una tasa de éxito de $85+/-18 \%$ y el grupo de prueba tuvo una tasa de éxito de $95+/-4 \%$. Las tasas de éxito variables $(p=0,36)$ no presentaron una diferencia estadísticamente significativa. La CAF aislada o su asociación con SCTG mostraron resultados favorables en los tratamientos de las recesiones gingivales de clase I y II de Miller.

PALABRAS CLAVE: periodoncia, investigación dental, odontología.

\section{REFERENCES}

Baldi, C.; Pini-Prato, G.; Pagliaro, U.; Nieri, M.; Saletta, D.; Muzzi, L. \& Cortellini, P. Coronally advanced flap procedure for root coverage. Is flap thickness a relevant predictor to achieve root coverage? A 19-case series. J. Periodontol., 70(9):1077-84, 1999.

Berlucchi, I.; Francetti, L.; Fabbro, M. D.; Basso, M. \& Weinstein, R. $L$. The influence of anatomical features on the outcome of gingival recessions treated with coronally advanced flap and enamel matrix derivative: a 1-year prospective study. J. Periodontol., 76(6):899-907, 2005.

Castellanos, T. A.; de la Rosa, R. M.; de la Garza, M. \& Caffesse, R. $\mathrm{G}$. Enamel matrix derivative and coronal flaps to cover marginal tissue recessions. J. Periodontol., 77(1):7-14, 2006

Chambrone, L.; Sukekava, F.; Araújo, M. G.; Pustiglioni, F. E.; 
Chambrone, L. A. \& Lima, L. A. Root-coverage procedures for the treatment of localized recession-type defects: a Cochrane systematic review. J. Periodontol., 81(4):452-78, 2010.

Chaparro, A.; De la Fuente, M.; Albers, D.; Hernandez, D.; Villalobos, A. M.; Gaedechens, D.; De la Fuente, M. \& De la Fuente, M. Root Coverage of Multiple Miller Class I and II Recession Defects Using Acellular Dermal Matrix and Tunneling Technique in Maxilla and Mandible: A 1-Year Report. Int. J. Periodontics Restor. Dent., 35(5):639-45, 2015.

Cortellini, P.; Tonetti, M.; Baldi, C.; Francetti, L.; Rasperini, G.; Rotundo, R.; Nieri, M.; Franceschi, D. \& Pini Prato, G. Does placement of a connective tissue graft improve the outcomes of coronally advanced flap for coverage of single gingival recessions in upper anterior teeth? A multi-centre, randomized, double-blind, clinical trial. J. Clin. Periodontol., 36(1):68-79, 2009.

Guttiganur, N.; Aspalli, S.; Sanikop, M. V.; Desai, A.; Gaddale, R. \& Devanoorkar, A. Classification systems for gingival recession and suggestion of a new classification system. Indian J. Dent. Res., 29(2):233-77, 2018.

Hwang, D. \& Wang, H. L. Flap thickness as a predictor of root coverage: a systematic review. J. Periodontol., 77(10):1625-34, 2006.

Kang, T. \& Fien, M. J. Introduction to the SES technique: a composite of surgical modifications which simplify the subepithelial connective tissue graft technique. Compend. Contin. Educ. Dent., 29(3):1724, 2008.

Minsk, L. Periodontal plastic surgery procedures: subepithelial connective tissue graft for root coverage. Compend. Contin. Educ. Dent., 23(11):1016-20, 2002.

Nart, J. \& Valles, C. Subepithelial Connective Tissue Graft in Combination with a Tunnel Technique for the Treatment of Miller Class II and III Gingival Recessions in Mandibular Incisors: Clinical and Esthetic Results. Int. J. Periodontics Restor. Dent., 36(4):5918, 2016.

Nart, J.; Valles, C.; Mareque, S.; Santos, A.; Sanz-Moliner, J. \& Pascual, A. Subepithelial connective tissue graft in combination with a coronally advanced flap for the treatment of Miller Class II and III gingival recessions in mandibular incisors: a case series. Int. J. Periodontics Restor. Dent., 32(6):647-54, 2012.

Pini Prato, G. P.; Baldi, C.; Nieri, M.; Franseschi, D.; Cortellini, P.; Clauser, C.; Rotundo, R. \& Muzzi, L. Coronally advanced flap: The post-surgical position of the gingival margin is an important factor for achieving complete root coverage. J. Periodontol., 76(5):713-22, 2005.

Pini Prato, G. P.; Franceschi, D.; Cortellini, P. \& Chambrone, L. Longterm evaluation (20 years) of the outcomes of subepithelial connective tissue graft plus coronally advanced flap in the treatment of maxillary single recession-type defects. J. Periodontol., 89(11):1290-9, 2018.

Pini Prato, G.; Pagliaro, U.; Baldi, C.; Nieri, M.; Saletta, D.; Cairo, F. \& Cortellini, P. Coronally advanced flap procedure for root coverage. Flap with tension versus flap without tension: A randomized controlled clinical study. J. Periodontol., 71(2):188-201, 2000.

Roman, A.; Soanca, A.; Kasaj, A. \& Stratul, S. I. Subepithelial connective tissue graft with or without enamel matrix derivative for the treatment of Miller class I and II gingival recessions: a controlled randomized clinical trial. J. Periodontal Res., 48(5):56372, 2013.

Rubins, R. P.; Tolmie, P. N.; Corsig, K. T.; Kerr, E. N. \& Kim, D. M. Subepithelial connective tissue graft with growth factor for the treatment of maxillary gingival recession defects. Int. J. Periodontics Restor. Dent., 33(1):43-50, 2013.

Saletta, D.; Prato, G. P.; Pagliaro, U.; Baldi, C.; Mauri, M. \& Nieri, M. Coronally advanced flap procedure: is the interdental papilla a prognostic factor for root coverage? J. Periodontol., 72(6):7606, 2001.

Sculean, A.; Cosgarea, R.; Katsaros, C.; Arweiler, N. B.; Miron, R. J.
\& Deppe, $\mathrm{H}$. Treatment of single and multiple Miller Class I and III gingival recessions at crown-restored teeth in maxillary esthetic areas. Quintessence Int., 48(10):777-82, 2017.

Sculean, A.; Cosgarea, R.; Stahli, A.; Katsaros, C.; Arweiler, N. B.; Brecx, M. \& Deppe, H. The modified coronally advanced tunnel combined with an enamel matrix derivative and subepithelial connective tissue graft for the treatment of isolated mandibular Miller Class I and II gingival recessions: a report of 16 cases. Quintessence Int., 45(10):829-35, 2014.

Sculean, A.; Cosgarea, R.; Stahli, A.; Katsaros, C.; Arweiler, N. B.; Miron, R. J. \& Deppe, H. Treatment of multiple adjacent maxillary Miller Class I, II, and III gingival recessions with the modified coronally advanced tunnel, enamel matrix derivative, and subepithelial connective tissue graft: a report of 12 cases. Quintessence Int., 47(8):653-9, 2016.

Straub, B.; Freidel, M. \& Breton, P. Paradontal plastic surgery: treatment of gingival recession using a gliding flap with a deep conjunctive graft. Rev. Stomatol. Chir. Maxillo-Fac., 107(5):361$5,2006$.

Ucak, O.; Ozcan, M.; Seydaoglu, G. \& Haytac, M. C. Microsurgical instruments in laterally moved, coronally advanced flap for Miller Class III isolated recession defects: a randomized controlled clinical trial. Int. J. Periodontic Restor. Dent., 37(1):109-15, 2017.

Van Zyl, A. W. \& Botha, P. J. The use of subepithelial connective tissue grafts in the treatment of marginal recession defects-a surgical approach. SADJ, 56(11):540-3, 2001.

Zucchelli, G. \& De Sanctis, M. Long-term outcome following treatment of multiple Miller class I and II recession defects in esthetic areas of the mouth. J. Periodontol., 76(12):2286-92, 2005.

Zucchelli, G. \& De Sanctis, M. Modified two-stage procedures for the treatment of gingival recession. Eur. J. Esthet. Dent., 8(1):2442, 2013.

Zucchelli, G. \& De Sanctis, M. Treatment of multiple recession-type defects in patients with esthetic demands. J. Periodontol., 71(9):1506-14, 2000.

\section{Corresponding author:}

Jefferson David Melo de Matos

Department of Dental Materials and Prosthodontics

São Paulo State University (Unesp)

Institute of Science and Technology

São José dos Campos - SP

Avenue Engenheiro Francisco José Longo -777/778

Jardim São Dimas

São José dos Campos

BRAZIL

Email: matosjefferson19@gmail.com

Received: 16-03-2019

Accepted: $30-03-2020$ 